\title{
PERKEMBANGAN DESA WISATA JATILUWIH \\ SETELAH UNESCO MENETAPKAN SUBAKNYA \\ SEBAGAI BAGIAN DARI WARISAN BUDAYA DUNIA
}

\author{
Dewa Ayu Diyah Sri Widari \\ Email: dewaayusriwidari@gmail.com
}

\begin{abstract}
This article identifies the social, cultural, and economic development of Jatiluwih tourism village after subak (rice field and its irrigation cultural system) in this village was decreed by UNESCO as a World's Cultural Heritage in 2012, under the label Cultural Landscape of Bali Province: the Subak System as a Manifestation of the Tri Hita Karana. It also discusses tourists' perception to the rice field tourist attraction. The data were collected through observation, interview, and documentary study, and then descriptively and qualitatively analyzed. The informants were selected using the purposive sampling technique and the accidental sampling technique. The study shows that the mutual cooperation, the rituals related to the farming activities, and rice planting system were still well maintained by farmers of the subak member. The traditional arts were conserved and developed, and the social organization were also well maintened. The economic aspects which includes job and business opportunities, income and investment have improved. The local people's participation in the planning and controlling phases were manipulative and functional. In the development phase, the local people participated actively. While tourist's perception on subak is good, but that is not the case on the poor condition of public facilities and information service by local management.
\end{abstract}

Keywords: tourism village, subak, world cultural heritage, tri hita karana.

\section{Pendahuluan}

Tahun 2012 merupakan salah satu tonggak penting dalam dunia kepariwisataan Bali dilihat dari konteks pengembangan pariwisata budaya. Dikatakan penting karena pada tahun 2012, Pemprov Bali menegaskan kembali pariwisata budaya sebagai landasan pengembangan kepariwisataan Bali lewat penetapan Peraturan Daerah Provinsi Bali Nomor 2 Tahun 2012 
tentang Kepariwisataan Budaya Bali. Untuk pertama kali, Perda Pariwisata Budaya ditetapkan tahun 1974, lalu direvisi tahun 1991, dan kemudian tahun 2012, rangkaian revisi atau penyempurnaa ketiga kali yang menunjukkan betapa sentralnya budaya dalam kepariwisataan. Selain itu, pada bulan Juni 2012, Bali mendapat pengakuan istimewa dari UNESCO dengan penetapan subak sebagai warisan budaya dunia dengan label Cultural Landscape of Bali Province: the Subak System as a Manifestation of the Tri Hita Karana Philosophy (Lanskap budaya Bali: Sistem Subak sebagai Manifestasi Filosofi Tri Hita Karana). Tri Hita Karana adalah filosofi Hindu yang berarti tiga penyebab kesejahteraan yaitu harmonisnya hubungan antara manusia dengan Tuhan (parhyangan), dengan manusia (pawongan), dan manusia dengan alam (palemahan).

Dalam penetapan lanskap budaya Bali atau subak sebagai warisan budaya dunia, maka perhatian public di Bali dan Indonesia tertuju pada kawasan persawahan luas di Desa Jatiluwih. Desa Jatiluwih merupakan desa wisata yang berlokasi di Kecamatan Penebel, Kabupaten Tabanan. Desa wisata ini memiliki panorama alam yang indah dengan keunikan sawah berundakundak yang berada di kaki Gunung Batukaru. Udaranya relatif sejuk karena berada pada ketinggian 700 meter dari permukaan laut. Pola hidup masyarakat di Desa Wisata Jatiluwih bersifat agraris religius (Lihat Foto 1).

Tujuan umum penataan dan pengembangan desa wisata adalah memberikan model pembangunan pariwisata yang mungkin berdampingan dengan dan bahkan mengembangkan budaya setempat, dan mendukung konsep pembangunan yang berkesinambungan, memberikan pemerataan kesempatan berusaha, serta peningkatan daya dukung desa dengan pranata sosial kepariwisataan dan peningkatan kualitas pengelolaan (Universitas Gadjah Mada, 1992:3).

Berdasarkan tujuan umum yang ingin dicapai dalam penataan dan pengembangan desa wisata tersebut, ternyata tidak sesuai dengan realita yang terjadi di Desa Wisata Jatiluwih. Menurut penelitian yang dilakukan oleh Prasiasa (2010) pengembangan pariwisata di Desa Wisata Jatiluwih kurang memberikan manfaat ekonomi bagi masyarakat lokal, menimbulkan komodifikasi pada bangunan tradisional saka roras, semakin meningkatnya penjualan tanah di sekitar pura dan hutan sebelah utara Pura Luhur Petali.

Kunjungan wisatawan ke Desa Wisata Jatiluwih setelah penetapan subak sebagai Warisan Budaya Dunia, mengalami peningkatan. Pada tahun 2012 jumlah kunjungan wisatawan sebanyak 97.909 orang, sedangkan tahun 2013 sebanyak 101.560 orang, terjadi peningkatan sebesar 37,28\%. Tahun 2014 jumlah kunjungan wisatawan sebanyak 165.158. Jika jumlah kunjungan wisatawan tahun 2013 dibandingkan dengan jumlah kunjungan wisatawan tahun 2014, terjadi peningkatan sebesar 62,62\% (Diparda Provinsi Bali, 2015). 


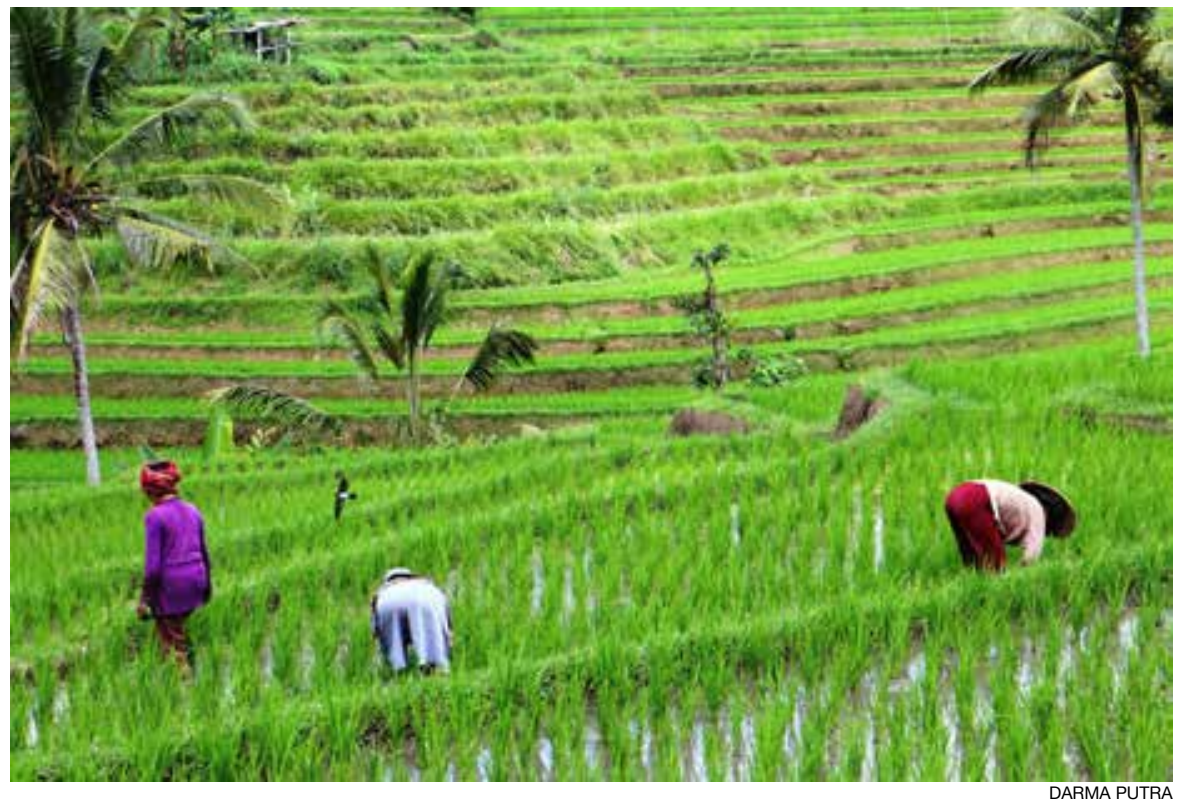

Foto 1: Hamparan sawah luas berundak di Desa Jatiluwih. Aktivitas bertani menambah daya tarik wisata ini.

Pendapatan masyarakat yang diterima secara langsung dari berkembangnya lapangan kerja dan kesempatan berusaha akibat perkembangan desa wisata juga meningkat. Namun, peningkatan tersebut belum memberikan manfaat ekonomi yang optimal bagi masyarakat lokal. Perkembangan Desa Wisata Jatiluwih juga memberi dampak pada berkembangnya kehidupan sosial budaya masyarakat setempat. Di sisi lain, juga menimbulkan pergeseran pada budaya pertanian yang diterapkan oleh masyarakat lokal.

Mengacu pada tujuan pembangunan pariwisata yang berbasis pada pemberdayaan masyarakat serta International Council of Monument and Site (ICOMOS), masyarakat harus dilibatkan dalam pengembangan pariwisata. Menurut Prasiasa (2010) masyarakat Jatiluwih kurang berpartisipasi dalam pengembangan desanya. Di samping itu, menurut Heny Urmila Dewi dkk. (2013) partisipasi masyarakat Jatiluwih pada tahap perencanaan, implementasi, dan pengawasan masih minim.

Perkembangan suatu desa wisata memerlukan kerjasama dan keterlibatan seluruh masyarakat di desa tersebut untuk memajukannya. Dengan dibentuknya Badan Pengelola Daya Tarik Wisata, masyarakat Desa Jatiluwih sudah mulai aktif dalam mengelola desa wisata. Partisipasi masyarakat dalam pengembangan desa wisata, baik pada pengelolaan fasilitas pariwisata maupun keterlibatan pada badan pengelola. Namun, dalam perencanaan dan pengawasan desa wisata, masyarakat kurang dilibatkan.

Untuk menciptakan pengelolaan sumber daya di bidang pariwisata yang 
mampu melibatkan masyarakat lokal dalam menjaga keseimbangan dan keharmonisan lingkungan hidup, sumber daya dan kepuasan wisatawan guna keberlanjutan sistem sosial, budaya, dan ekonomi, pengembangan pariwisata di Bali tidak bisa dilepaskan dari kearifan lokal Tri Hita Karana. Untuk itulah perlu mengkaji persepsi wisatawan terhadap perkembangan Desa Wisata Jatiluwih setelah penetapan subak sebagai Warisan Budaya Dunia dari aspek parhyangan, pawongan, dan palemahan.

Berdasarkan latar belakang, rumusan masalah dalam artikel ini adalah (1) bagaimana perkembangan sosial budaya dan ekonomi Desa Wisata Jatiluwih setelah penetapan subak sebagai Warisan Budaya Dunia dari aspek Tri Hita Karana, (2) bagaimana partisipasi masyarakat dalam perkembangan Desa Wisata Jatiluwih setelah penetapan subak sebagai Warisan Budaya Dunia dari aspek Tri Hita Karana, dan (3) bagaimana persepsi wisatawan terhadap perkembangan Desa Wisata Jatiluwih setelah penetapan subak sebagai Warisan Budaya Dunia dari aspek Tri Hita Karana.

\section{Teori dan Metode}

Teori yang digunakan untuk menganalisis permasalahan dalam artikel ini adalah teori siklus hidup destinasi, teori konflik, teori dampak, teori partisipasi, dan teori persepsi. Adapun uraian dari masing-masing teori tersebut sebagai berikut. Tujuan utama dari penggunaan model siklus hidup destinasi adalah sebagai alat untuk memahami evolusi dari produk dan destinasi pariwisata. Siklus hidup pariwisata mengacu pada pendapat Butler (1980) tentang tourism area life cycle dengan tahapan yaitu exploration, involvement, development, consolidation, stagnation, dan decline atau rejuvenation.

Teori Konflik menolak anggapan bahwa masyarakat ada dalam situasi stabil dan tidak berubah. Sebaliknya, masyarakat selalu dilihat dalam suatu kondisi tidak seimbang atau tidak adil, dan keadilan/keseimbangan dapat dicapai dengan penggunaan kekuatan revolusi terhadap kelompokkelompok yang memegang kekuasaan (Pitana dan Gayatri, 2005:20).

Menurut Higo Tugiman (dalam Musoman, dkk., 2013) dampak merupakan pengawasan internal sangat penting, dengan mudah dapat diubah menjadi sesuatu yang dipahami dan ditanggapi secara serius oleh manajemen. Pengembangan pariwisata dapat menimbulkan berbagai dampak, baik pengaruh positif maupun negatif. Cooper, dkk. (1999:133), menyebutkan bahwa pengeluaran wisatawan memiliki efek bertingkat di seluruh perekonomian penduduk setempat.

Timothy (1999) menyebutkan ada dua perspektif untuk melihat partisipasi masyarakat dalam pariwisata. Kedua perspektif tersebut adalah partisipasi masyarakat lokal dalam proses pengambilan keputusan, dan berkaitan dengan manfaat yang diterima masyarakat dari pembangunan pariwisata. 
Persepsi didefinisikan sebagai proses yang dilalui seseorang dalam memilih, mengatur, dan menginterpretasikan masukan-masukan informasi untuk menciptakan gambaran yang berarti tentang dunia (Cravens, 1997:131).

Konsep yang digunakan dalam artikel ini adalah perkembangan, desa wisata, subak, Warisan Budaya Dunia, dan Tri Hita Karana. Artikel ini merupakan hasil penelitian dengan pendekatan penelitian kualitatif. Data dikumpulkan melalui observasi, wawancara dan studi dokumen. Data yang terkumpul dianalisis secara deskriptif kualitatif. Teknik penentuan informan dengan purposive sampling dan accidental sampling. Berdasarkan tujuan serta pertimbangan peneliti, informan yang diambil terdiri atas Kepala Desa, Bendesa Adat, Pekaseh, Kelian Dusun, Pengelola Desa Wisata, Pengusaha Pariwisata, masyarakat dan wisatawan.

\section{Jatiluwih setelah Subak menjadi Warisan Budaya Dunia 3.1 Perkembangan Sosial Budaya}

Perkembangan sosial budaya Desa Wisata Jatiluwih setelah penetapan subak sebagai Warisan Budaya Dunia meliputi aspek kegotongroyongan, budaya pertanian, kesenian tradisional, dan organisasi sosial.

Kegotongroyongan. Kegotongroyongan dalam hal pelaksanaan adat dan suka duka, di kalangan masyarakat Desa Jatiluwih masih terjaga bahkan semakin baik. Pada saat dilaksanakan upacara adat seperti pujawali/ piodalan di pura kahyangan tiga, ngusaba desa, dan pura-pura lain yang tergolong pura dang kahyangan, masyarakat mempersiapkan segala keperluan upacara tersebut secara gotong-royong. Kegotongroyongan dalam kaitannya dengan suka duka juga masih terpelihara. Apabila ada salah satu keluarga yang mengalami musibah kematian, warga masyarakat lainnya akan membantu dalam proses upacara yang dilaksanakan sehubungan dengan terjadinya kematian tersebut.

Kebersamaan berupa kegotongroyongan di kalangan masyarakat Desa Jatiluwih yang masih dijaga, mencerminkan implementasi positif aspek pawongan dari konsep Tri Hita Karana. Rasa kekeluargaan dan solidaritas yang tinggi membuat terjalinnya harmonisasi di antara masyarakat setempat. Hal ini perlu terus dijaga dan dipertahankan agar kehidupan bermasyarakat di Desa Jatiluwih dapat berjalan dalam suasana yang harmonis.

Budaya Pertanian. Budaya pertanian yang diterapkan oleh warga subak terus dilaksanakan, yaitu upacara yang berkaitan dengan aktivitas pertanian, antara lain upacara mapag toya, kempelan, upacara ngendag tanah carik, upacara ngurit, upacara ngerasakin, upacara pangawiwit (nuwasen), upacara ngekambuhin, upacara pamungkah, upacara penyepian, upacara pangarestitian nyegara gunung, upacara mesaba, ngadegang Batari Sri (Batari Nini), upacara nganyarin dan manyi. Semua upacara tersebut terus 
diselenggarakan oleh masing-masing warga subak sebagai suatu kebiasaan (tradisi) yang memang harus dilaksanakan (hasil wawancara dengan Pekaseh Subak Jatiluwih dan Kepala Dusun di Desa Jatiluwih tanggal 2 Januari 2015).

Selain upacara yang berkaitan dengan aktivitas petani di sawah, sistem tanam padi juga terus diterapkan oleh warga subak. Subak Jatiluwih membagi sistem tanam padi menjadi dua periode. Periode pertama, penanaman padi Bali (lokal) pada bulan Januari, dengan masa panen antara bulan Mei dan Juni. Periode kedua, penanaman padi varietas (Serang, Mangsur, Sigelis, PB dan IR) pada bulan Agustus, dengan masa panen pada bulan Nopember. Sistem tanam padi tersebut sudah diterapkan sejak tahun 1977/1978. Penerapan sistem tanam padi Bali (lokal) sebagai upaya untuk mempertahankan ketersediaan beras merah cendana, beras putih (ketan), dan beras hitam (injin) sebagai perlambang tri datu. Tiga warna tersebut disakralkan oleh umat Hindu yaitu merah, putih dan hitam (hasil wawancara dengan Pekaseh Subak Jatiluwih tanggal 2 Januari 2015).

Budaya pertanian dalam pelaksanaan upacara yang berkaitan dengan aktivitas pertanian dan sistem tanam padi memang terus dilaksanakan. Akan tetapi, dari pola tanam padi yang diterapkan oleh warga subak telah terjadi pergeseran. Pergeseran terjadi sebagai akibat adanya arus modernisasi dalam bidang pertanian yang melanda petani-petani di wilayah Bali termasuk di Desa Jatiluwih. Modernisasi dalam bidang pertanian, yaitu penggunaan traktor untuk membajak sawah dan penggunaan pupuk anorganik (urea) untuk menyuburkan tanah dan tanaman pertanian.

Kesenian Tradisional. Kesenian tradisional yang ada di Desa Jatiluwih antara lain Baris Memedi (Baris Keraras), Baris Tombak, Topeng Sidakarya, Topeng Perembon, Joged Bumbung, Wayang, Angklung, Sekaha Gong Lanang, dan Sekaha Gong Istri. Dengan dijadikannya Desa Jatiluwih sebagai Desa Wisata dan ditetapkannya subak sebagai Warisan Budaya Dunia oleh UNESCO, keberadaan kesenian tradisional semakin dilestarikan dan dikembangkan.

Organisasi Sosial. Seiring dengan perkembangannya, keberadaan desa adat di Desa Jatiluwih masih tetap dihormati sebagai organisasi sosial tradisional. Menurut Bendesa Adat Jatiluwih dan Bendesa Adat Gunungsari, hal-hal yang berkaitan dengan adat serta permasalahan mengenai adat, ditangani dan diatur oleh desa adat. Dari leluhur terdahulu, apabila ada masyarakat yang menghadapi permasalahan adat akan diselesaikan bersama antara pengurus desa adat dan warga desa, hal ini masih berlaku sampai saat ini.

Selain desa adat sebagai organisasi sosial yang mengurus tentang adat, di Desa Jatiluwih terdapat organisasi tradisional dalam bidang kesenian. Organisasi bidang kesenian (sekaha) yang dimiliki Desa Jatiluwih yaitu 


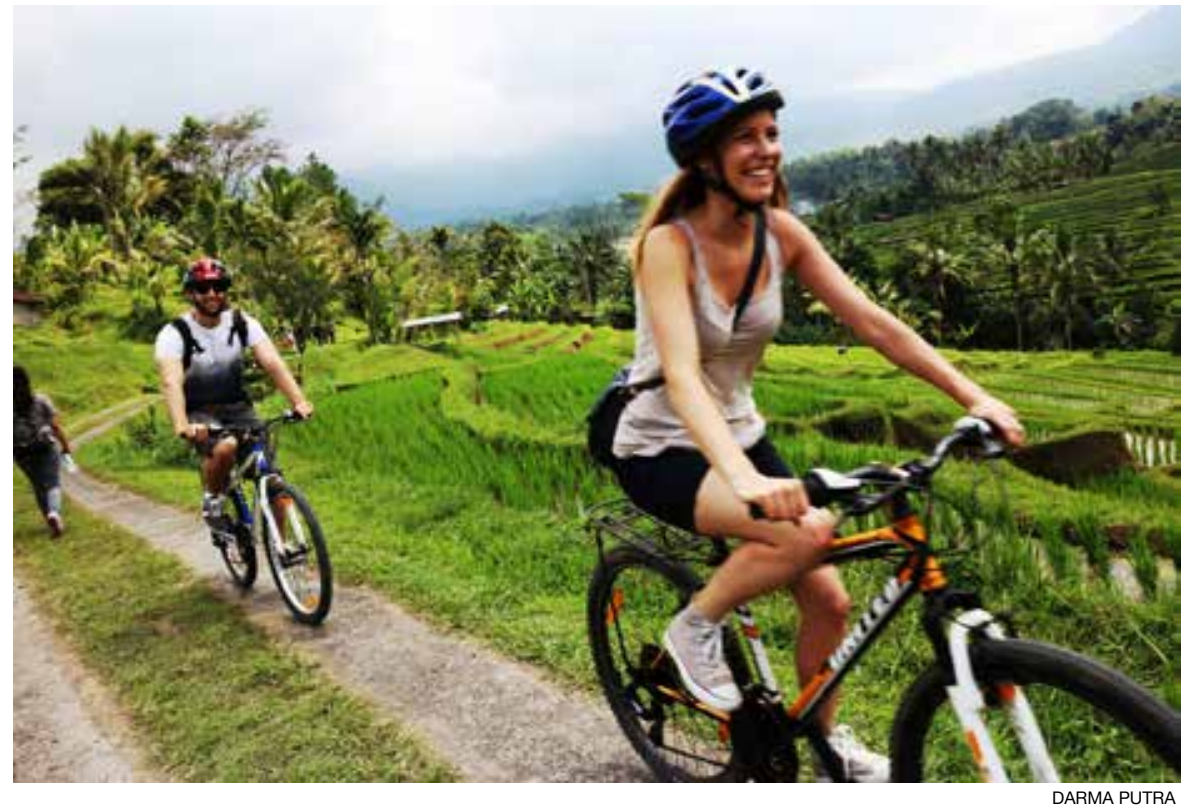

Foto 2. Wisatawan menikmati pesona sawah Jatiluwih dengan bersepeda.

Sekaha Angklung, Sekaha Gong Lanang, Sekaha Gong Istri, dan Sekaha Shanti. Organisasi bidang kesenian (sekaha-sekaha) tersebut terus dilestarikan dan dikembangkan.

Disamping keindahan terasering sawah sebagai daya tarik wisata, keberadaan subak juga merupakan potensi lain yang dimiliki Desa Wisata Jatiluwih. Subak sebagai organisasi tradisional yang mengatur pengairan, merupakan organisasi sosial yang diwarisi secara turun-temurun oleh masyarakat setempat. Berkembangnyajaman tidak mempengaruhi eksistensi Subak Jatiluwih, terlebih lagi dengan ditetapkannya subak sebagai Warisan Budaya Dunia. Masyarakat Jatiluwih mayoritas bermata pencaharian sebagai petani, semakin termotivasi untuk menjaga keberadaan subak.

Desa adat sebagai organisasi sosial yang mengatur hubungan antar warga Desa Jatiluwih mengenai hal-hal yang berkaitan dengan adat. Subak sebagai organisasi yang mengatur segala sesuatu yang berhubungan dengan pertanian milik warga desa. Kedua organisasi tersebut tetap dijaga keberadaannya, sebagai wujud penerapan aspek pawongan di kalangan masyarakat setempat.

\subsection{Perkembangan Ekonomi}

Perkembangan ekonomi Desa Wisata Jatiluwih setelah penetapan subak sebagai Warisan Budaya Dunia meliputi lapangan kerja dan kesempatan berusaha, pendapatan serta investasi.

Lapangan Kerja dan Kesempatan Berusaha. Perkembangan 
pariwisata di Desa Jatiluwih memberi dampak terhadap lapangan pekerjaan. Sejak ditetapkan sebagai desa wisata dan daya tarik wisata, jumlah kunjungan wisatawan ke Desa Wisata Jatiluwih mengalami peningkatan (Lihat Foto 2). Meningkatnya jumlah kunjungan wisatawan, diiringi juga dengan peningkatan fasilitas/sarana pariwisata yang diperlukan untuk menunjang perkembangan pariwisata.

Setelah penetapan subak sebagai warisan Budaya Dunia, jumlah tenaga kerja yang terserap dari usaha pariwisata mengalami peningkatan. Jumlah tenaga kerja langsung pada usaha pariwisata di Desa Wisata Jatiluwih sebelum penetapan subak sebagai Warisan Budaya Dunia sebanyak 48 orang. Setelah penetapan meningkat menjadi 63 orang, dari jumlah tersebut $68,25 \%$ atau 43 orang berasal dari Desa Jatiluwih dan $31,75 \%$ atau 20 orang berasal dari luar Desa Jatiluwih.

Pendapatan. Pendapatan yang diterima oleh masyarakat Desa Wisata Jatiluwih berasal dari usaha-usaha pariwisata maupun pengelolaan desa wisata. Dari usaha pariwisata, pendapatan yang diterima oleh pengusaha pariwisata mengalami peningkatan. Pengusaha pariwisata mengemukakan bahwa setelah penetapan subak sebagai Warisan Budaya Dunia, pendapatan dari usaha yang ditekuni meningkat sebesar 20\% sampai $40 \%$.

Setelah penetapan subak sebagai Warisan Budaya Dunia, dari pendapatan kotor (bruto) yang diterima oleh Badan Pengelola Daya Tarik Wisata Jatiluwih, setelah dikurang asuransi maka diperoleh pendapatan bersih (netto). Selanjutnya, pendapatan netto didistribusikan untuk manajemen operasional $15 \%$, pengembangan $10 \%$, promosi $5 \%$, dan badan pengelola 10\%. Kemudian, dari sisa pendapatan tersebut didistribusikan lagi untuk Pemerintah Daerah Kabupaten Tabanan 45\% dan untuk desa 55\%. Pendapatan yang diterima oleh desa, didistribusilkan lagi, yaitu untuk Desa Dinas 25\%, Desa Adat Jatiluwih 30\%, Desa Adat Gunungsari 20\%, Subak Jatiluwih 21\%, Subak Abian Jatiluwih 2\%, dan Subak Abian Gunungsari 2\%.

Pendapatan yang diperoleh Badan Pengelola Daya Tarik Wisata Jatiluwih berupa pendapatan kotor (bruto) tahun 2011 sebesar Rp 466.593.000,00. Pada tahun 2012 pendapatan kotor sebesar Rp 804.010.400,00 terjadi peningkatan 72,31\% dari tahun 2011. Tahun 2013 jumlah pendapatan kotor sebesar Rp 1.509.795.500,oo terjadi peningkatan 87,78\% dari tahun 2012. Tahun 2014 (sampai Nopember) pendapatan kotor sebesar Rp. 3.001.059.500,00 terjadi peningkatan sebesar 98,77\% dari tahun 2013.

Pendapatan yang diterima dari pengelolaan desa wisata oleh desa adat, dan subak dipergunakan untuk membiayai upacara keagamaan. Dengan adanya pembagian pendapatan untuk desa adat dan subak, masyarakat Desa Jatiluwih tidak perlu lagi membayar iuran wajib pada saat ada upacara keagamaan. Bagi masyarakat setempat, hal ini dapat meringankan biaya yang harus dikeluarkan untuk upacara keagamaan. Secara tidak langsung, 


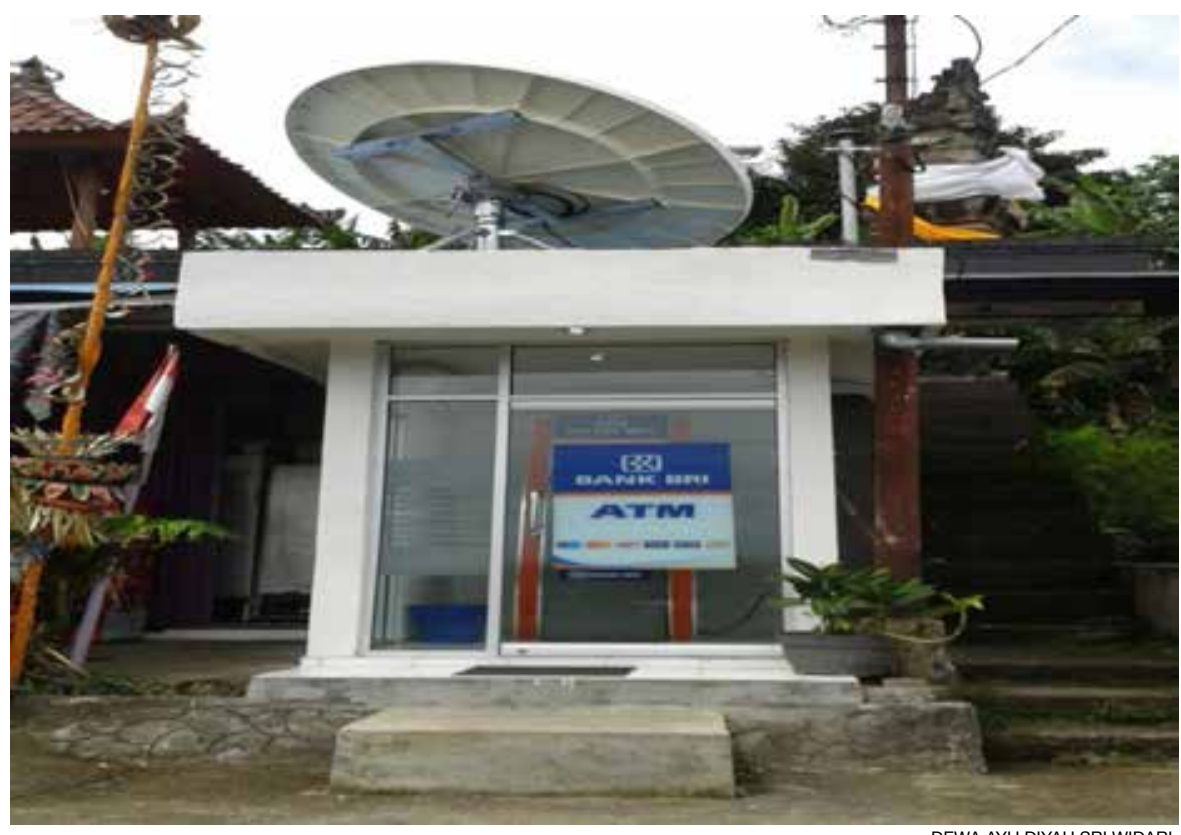

Foto 3. Fasilitas ATM di Desa Jatiluwih.

masyarakat juga mendapat manfaat dari pengelolaan desa wisata.

Investasi. Berkembangnya Desa Wisata Jatiluwih, mendorong masyarakat untuk berinvestasi secara langsung dalam usaha-usaha pariwisata. Usaha-usaha pariwisata seperti homestay, restoran, warung makan, dan penyewaan ATV (All Train Vehicle), sebagian besar modalnya berasal dari masyarakat setempat. Di samping investasi dalam usaha-usaha pariwisata yang dimiliki oleh masyarakat, setelah penetapan subak sebagai Warisan Budaya Dunia, terjadi penambahan investasi. Di sebelah selatan Puskesmas yang berdekatan dengan kantor Badan Pengelola Daya Tarik Wisata Jatiluwih, dibangun fasilitas Anjungan Tunai Mandiri (ATM) Bank Rakyat Indonesia. ATM tersebut dapat dipergunakan untuk bertransaksi mempergunakan VISA, Master Card, Cirrus, Link, dan ATM Bersama. Di areal parkir kendaraan (sebelah timur Billy's Terrace Cafe) juga sudah dibangun fasilitas toilet umum bagi wisatawan dengan kondisi kebersihan yang baik. Fasilitas ATM Bank Rakyat Indonesia di Desa Wisata Jatiluwih seperti Foto 3 .

\section{Partisipasi Masyarakat}

\subsection{Partisipasi pada Tahap Perencanaan}

Dalam pengembangan desa wisata, masyarakat Desa Jatiluwih kurang dilibatkan dalam proses pengambilan keputusan. Seperti pada kasus kontrak Billy's Terrace Cafe, pada awal pendiriannya kafe ini diberi nama 
Cafe Jatiluwih. Cafe Jatiluwih milik masyarakat Desa Jatiluwih karena pembangunannya atas inisiatif masyarakat desa dan dibangun di atas tanah pelabe (milik) Pura Dalem. Pada awalnya pengelolaan dilakukan oleh masyarakat desa setempat. Karena pengelolaannya kurang maksimal, keuntungan sulit dihasilkan, akhirnya kafe ini dikontrakkan oleh Desa Adat Jatiluwih. Namun pada proses pengambilan keputusan mengenai besarnya biaya sewa, jangka waktu kontrak, serta hal-hal lain yang berkaitan dengan perjanjian kontrak, masyarakat tidak dilibatkan.

Mengacu pada tipologi Pretty (dalam Mowforth dan Mount, 2000:146), partisipasi masyarakat pada tahap perencanan ini tergolong sebagai partisipasi manipulatif. Partisipasi manipulatif yaitu partisipasi orangorang yang mewakili organisasi resmi, tetapi mereka tidak terpilih dan tidak memiliki kekuasaan. Digolongkan demikian karena pada tahap ini masyarakat setempat memang dilibatkan dalam sosialisasi pengembangan Desa Wisata Jatiluwih, tetapi masyarakat tidak memiliki kekuasaan untuk menolak program-program yang sudah ditetapkan.

Implementasi aspek pawongan dari konsep Tri Hita Karana dalam partisipasi masyarakat pada tahap perencanaan tidak berjalan dengan baik. Masyarakat Desa Jatiluwih tidak dilibatkan pada proses pengambilan keputusan dalam pembangunan desanya. Masyarakat diikutsertakan dalam sosialisasi program-program kepariwisataan, namun tidak memiliki kemampuan untuk menolak program-program yang sudah ditetapkan. Hal ini menyebabkan terjadinya ketidakharmonisan hubungan antara masyarakat dengan badan pengelola, desa adat, dan pemerintah.

\subsection{Partisipasi pada Tahap Pengembangan}

Berdasarkan wawancara dengan pengusaha pariwisata (tanggal 2-3 Januari 2015), terdapat peningkatan jumlah usaha-usaha pariwisata yang terdapat di Desa Wisata Jatiluwih. Sebelum penetapan subak sebagai Warisan Budaya Dunia, jumlah usaha pariwisata yang ada sebanyak sembilan, yaitu Warung Makan Nadi, Warung Makan Sari Rasa, Galang Kangin Inn dan Warung Makan, Warung Terrace Subak, Warung Dhea, Warung Krisna, Billy's Terrace Cafe, Billy's Villas, dan Padi Bali. Setelah penetapan subak sebagai Warisan Budaya Dunia, terjadi penambahan pendirian usaha pariwisata yaitu restoran yang diberi nama J'Terrace, Warung Makan Wayan, dan Warung Terrace Subak menambah fasilitas rumah makan dengan fasilitas penginapan (berubah nama menjadi Warung Terrace Subak and Homestay).

Partisipasi masyarakat secara langsung dalam pengembangan desa wisata juga diwujudkan dengan terlibat pada pendirian dan operasional badan pengelola. Sekretariat Badan Pengelola Daya Tarik Wisata Jatiluwih seperti Foto 2. Pendirian badan pengelola sebagai upaya untuk dapat 
mengembangkan desa wisata secara profesional. Sebelum dibentuk badan pengelola, pengembangan desa wisata dikelola oleh desa dinas. Setelah pendirian badan pengelola, masyarakat lokal yang terlibat dan berpartisipasi dalam pengelolaan desa wisata semakin meningkat. Sumber Daya Manusia (SDM) yang dilibatkan dalam operasional dan manajemen diambil dari masing-masing dusun yang terdapat di Desa Jatiluwih.

Implementasi aspek pawongan dalam partisipasi masyarakat pada tahap pengembangan berjalan dengan baik. Masyarakat berpartisipasi dalam pengelolaan usaha-usaha pariwisata dan dilibatkan pada operasionalisasi badan pengelola daya tarik wisata. Dengan adanya pelibatan masyarakat tersebut, membuat terjalinnya keseimbangan hubungan antara masyarakat dengan badan pengelola.

\subsection{Partisipasi Pada Tahap Pengawasan}

Partisipasi yang dilakukan oleh masyarakat Desa Jatiluwih, pada tahap pengawasan untuk aspek operasional pengembangan desa wisata lebih bersifat praktis. Dalam hal ini, masyarakat yang bekerja pada badan pengelola daya tarik wisata melakukan pengawasan terhadap pelaksanaan operasionalisasi kegiatan desa wisata. Masyarakat melakukan pengawasan secara aktif dan langsung berdasarkan pada tugasnya masing-masing yang sudah ditentukan oleh badan pengelola. Pengawasan umumnya dilakukan oleh masyarakat yang bekerja sebagai petugas tiket, parkir, keamanan, dan pemandu wisata trekking.

Pengecekan ulang pembayaran retribusi yang dilakukan oleh petugas tiket sebagai bagian dari karyawan pada manajemen operasional Badan Pengelola Daya Tarik Wisata Jatiluwih, merupakan salah satu kewenangan yang diberikan oleh desa adat kepada karyawan bagian tiket. Petugas tiket memiliki wewenang untuk melakukan pengecekan ulang jumlah karcis yang terjual.

Selain pengawasan melekat yang dilakukan secara langsung oleh masyarakat lokal yang bekerja pada badan pengelola, untuk memantau perkembangan desa wisata, pengawasan juga dilakukan pada tingkat manajerial. Setelah penetapan subak sebagai Warisan Budaya Dunia, dibentuk Badan Pengelola Daya Tarik Wisata Jatiluwih berdasarkan Peraturan Bupati Tabanan Nomor 84 Tahun 2013 (Foto 4).

Bidang Pengawas bertugas untuk melakukan monitoring dan evaluasi terhadap perkembangan Desa Wisata Jatiluwih. Monitoring dilakukan terhadap program-program pengembangan desa wisata, baik mencakup aspek perencanaan dan pelaksanaan. Pelibatan pihak Pemerintah Kabupaten Tabanan (pihak eksternal) dalam pengawasan sebagai upaya untuk dapat memberikan arahan, bimbingan, dan kontrol dari kegiatan yang dilaksanakan. Namun, setelah kepengurusan berjalan selama kurang 


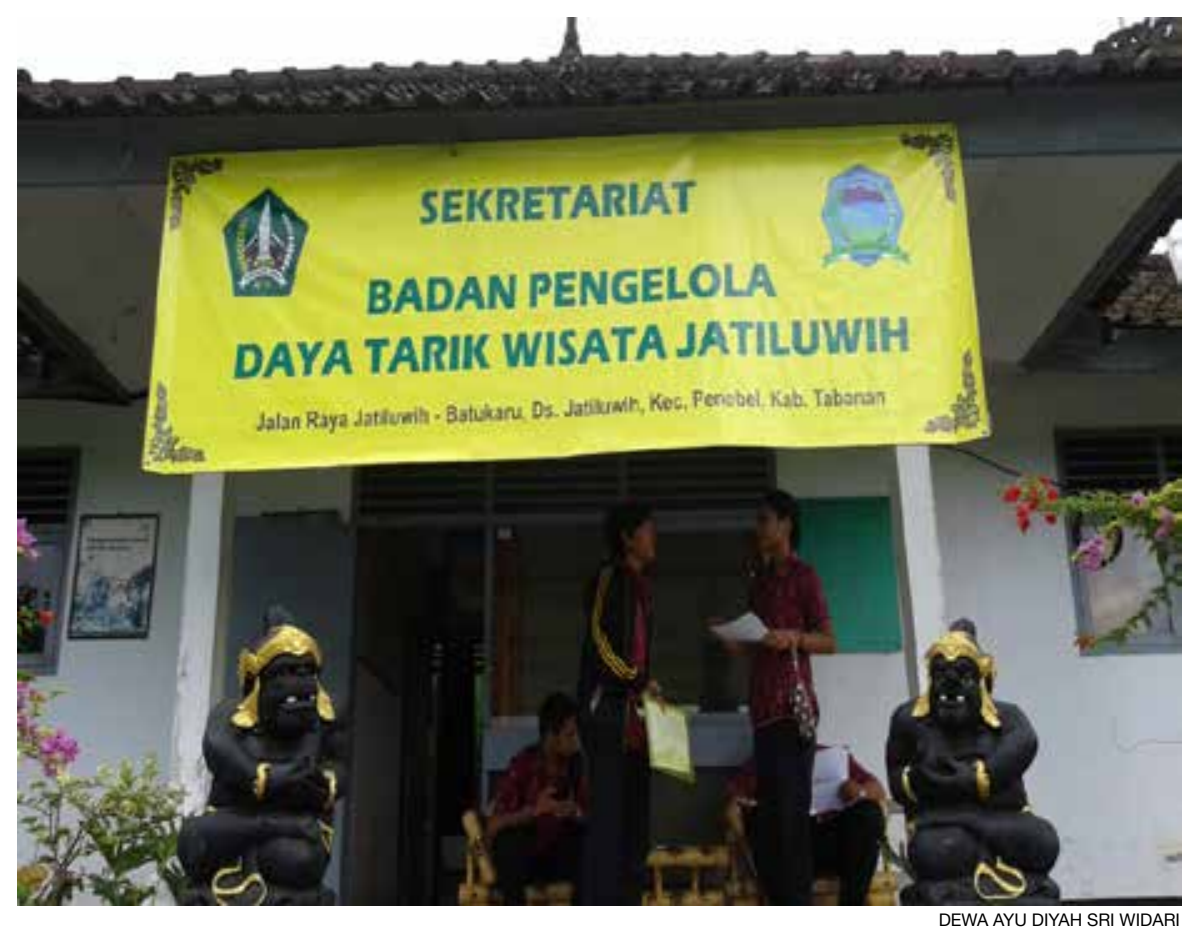

Foto 4. Kantor badan pengelola daya tarik wisata Jatiluwih.

lebih satu tahun, pengawasan yang dilakukan berjalan kurang efektif. Para pengurus khususnya pada Bidang Pengawas, memiliki kegiatan di kantor masing-masing sehingga jarang melaksanakan tugas sebagai pengawas pada Badan Pengelola Daya Tarik Wisata Desa Jatiluwih.

Meningkatnya jumlah kunjungan wisatawan setelah penetapan subak sebagai Warisan Budaya Dunia, berimplikasi pada peningkatan fasilitas pariwisata yang diperlukan. Kondisi ini menyebabkan terjadinya pembangunan fasilitas restoran dan rumah makan yang tidak terkendali serta tidak sesuai dengan aturan tata ruang. Fasilitas restoran dan rumah makan dibangun di atas lahan yang merupakan bagian dari Warisan Budaya Dunia, yang seharusnya tidak boleh ada pendirian bangunan. Pemilik lahan beranggapan bahwa mereka berhak dan bebas melakukan pembangunan karena lahan tersebut milik mereka sendiri. Bendesa Adat dan Pekaseh Subak Jatiluwih yang mengetahui tentang ketidaksesuaian tersebut lebih bersikap diam. Padahal seharusnya berhak melakukan pengawasan dan kontrol dari setiap pembangunan di daerahnya.

Pengawasan terhadap zonasi Warisan Budaya Dunia juga dilakukan oleh Pekaseh Subak Jatiluwih. Namun pengawasan tersebut mengalami kendala, selain disebabkan oleh kurangnya keterlibatan masyarakat dalam pembuatan perencanaan pengembangan desa wisata juga diakibatkan oleh 
belum adanya Peraturan Daerah yang secara khusus mengatur tentang zonasi di kawasan Warisan Budaya Dunia. Pekaseh beserta masyarakat tidak mengetahui apa yang direncanakan dan apa yang perlu diawasi. Masyarakat setempat tidak memiliki kompetensi untuk melakukan pengawasan. Claiborne (2010:42) menyatakan, jelas yang ideal bagi masyarakat untuk memutuskan bersama-sama bentuk dan fungsi perkembangan pariwisata dan memiliki kontrol penuh atas setiap skema pariwisata di lokasi mereka.

Partisipasi masyarakat pada pengawasan menyebabkan terjadinya konflik antara badan pengelola, pemerintah, dan masyarakat. Konflik ini merupakan indikasi tidak berjalannya implementasi pawongan. Harapan yang ditujukan kepada pemerintah daerah untuk lebih aktif melakukan pengawasan, pembinaan, dan pendampingan pada pengelolaan daya tarik wisata, juga tidak efektif. Hal ini menimbulkan ketidakpuasan masyarakat, dan memicu hubungan yang kurang harmonis antara pihak-pihak yang terkait.

\section{Persepsi Wisatawan}

Persepsi wisatawan terhadap perkembangan Desa Wisata Jatiluwih Setelah Penetapan Subak Sebagai Warisan Budaya Dunia mencakup implementasi pada aspek parhyangan, pawongan, dan palemahan.

\subsection{Persepsi Wisatawan terhadap Aspek Parhyangan}

Wisatawan yang berkunjung ke Desa Wisata Jatiluwih selain melihat terasering sawah, terdapat dua orang yang mengunjungi Pura Desa tempat penyelenggaraan upacara Ngusaba Desa. Anton dan Pieter Soder (wisatawan asal Belanda) mengungkapkan bahwa kondisi tempat suci (pura) terpelihara dengan baik. Kebersihan pura terjaga serta disediakannya tempat sampah di areal pura. Begitu memasuki pura, wisatawan diminta untuk mengenakan selendang sebagai persyaratan untuk masuk ke tempat suci. Wisatawan asal Belanda, dengan senang hati mentaati peraturan tersebut karena sudah mengetahui tata cara untuk masuk ke tempat suci dan sebagai bentuk penghormatan kepada masyarakat setempat (hasil wawancara tanggal 19 Maret 2015).

Wisatawan yang berkunjung menikmati terasering sawah seperti Pierre, Yuelle, Susan Allen, dan Lasandra Smith menyatakan palinggih yang ada pada tiap-tiap sawah milik petani kondisinya bagus. Bangunan palinggih pada sawah milik petani Desa Jatiluwih tergolong unik, karena atapnya ada yang menggunakan ijuk, mencerminkan bangunan tradisional Bali (hasil wawancara tanggal 19 Maret 2015).

Persepsi wisatawan terhadap perkembangan Desa Wisata Jatiluwih dari kondisi tempat suci yang terpelihara dengan baik, arsitektur palinggih yang unik sebagai apresiasi terhadap pelestarian budaya lokal, dan wisatawan 
mendapatkan pengalaman baru, merupakan bentuk implementasi aspek parhyangan yang masih terpelihara dengan baik.

\subsection{Persepsi Wisatawan terhadap Aspek Pawongan}

Pelayanan yang diberikan oleh petugas tiket memang ramah dan sopan, namun wisatawan tidak mendapatkan informasi yang diperlukan. Dari delapan orang wisatawan yang diwawancarai mengungkapkan seharusnya pada saat membeli tiket masuk, wisatawan diberikan informasi mengenai penggunaan uang retribusi sehingga wisatawan mengetahui pemanfaatan dari uang retribusi yang mereka bayarkan. Informasi lain yang berkaitan dengan daya tarik wisata juga tidak didapatkan oleh wisatawan. Padahal wisatawan memerlukan informasi mengenai sejarah, potensi yang dimiliki, dan hal-hal lain yang berkaitan dengan keberadaan subak sebagai Warisan Budaya Dunia.

Dari hasil wawancara, semua wisatawan menyatakan merasa aman pada saat melakukan kunjungan ke Desa Wisata Jatiluwih. Meskipun pada saat menikmati pemandangan terasering sawah, wisatawan memasuki areal persawahan tanpa ditemani oleh guide, wisatawan tetap merasa aman. Sesuai dengan persyaratan desa wisata, menurut Nuryanti (1993) bahwa keamanan desa tersebut harus terjamin.

Dari segi keamanan, wisatawan memberikan apresiasi yang baik, tetapi dari faktor kenyamanan tidak mendapatkan respons yang bagus. Semua wisatawan menyatakan tidak nyaman pada saat melakukan perjalanan baik dari arah Desa Senganan maupun dari arah Batukaru menuju Desa Wisata Jatiluwih yang disebabkan oleh jalan rusak.

Wisatawan asal Kanada, Susan Allen (berprofesi sebagai guru), secara kritis menyarankan perlu adanya kerja sama antara Badan Pengelola Daya Tarik Wisata Jatiluwih dan pemerintah untuk mengetahui perasaan serta pemahaman para petani tentang apa yang terjadi di Desa Wisata Jatiluwih dalam kaitannya dengan penetapan subak sebagai Warisan Budaya Dunia (hasil wawancara tanggal 19 Maret 2015).

Dalam pengembangan desa wisata, bukan hanya menjaga keharmonisan hubungan antara wisatawan dengan masyarakat (aspek pawongan), namun perlu juga menjaga keharmonisan antara petani dengan pengelola daya tarik wisata, dan pemerintah.

\subsection{Persepsi Wisatawan terhadap Aspek Palemahan}

Wisatawan yang menikmati panorama terasering sawah Jatiluwih, menyatakan kekagumannya dengan pemandangan alam yang dimiliki. Di samping mengagumi keindahan terasering sawah, wisatawan juga berpendapat pemandangan di sekitar areal persawahan masih alami. Hijaunya hamparan sawah dengan latar belakang Gunung Batukaru yang 
masih asri, sungai-sungai dengan airnya yang jernih, pepohonan yang masih banyak dijumpai sepanjang perjalanan, membuat wisatawan merasakan suasana pedesaan yang masih alami.

Selain persepsi positif wisatawan terhadap keunikan dan keindahan terasering sawah Jatiluwih, rata-rata wisatawan mengatakan bahwa kebersihan di sekitar daya tarik wisata sangat baik. Tidak ditemukan sampah di sekitar areal persawahan, sepanjang jalur trekking maupun pada fasilitas restoran yang dikunjungi. Penyediaan tempat sampah yang dipisahkan antara sampah organik dan anorganik, sudah sesuai dengan standar kebersihan. Dari segi jumlah, tempat sampah masih diperlukan penambahan.

Terasering sawah sebagai daya tarik wisata ditempatkan pada posisi utama sehingga wisatawan mudah untuk menikmati pemandangan. Jarak antara tempat parkir dengan lokasi terasering sawah yang cukup dekat, membuat wisatawan mudah untuk mengakses daya tarik wisata.

Semua wisatawan berpendapat bahwa fasilitas pariwisata yang disediakan kurang mencerminkan arsitektur tradisional Bali. Beberapa fasilitas pariwisata ada yang memakai arsitektur tradisional Bali, namun ada juga yang tidak. Kondisi ini tidak sesuai dengan konsep desa wisata, bukan hanya lingkungan yang mencerminkan suasana lokal, fasilitas pariwisata yang ditawarkan juga sebaiknya bernuansa tradisional (hasil wawancara tanggal 19 Maret 2015).

Fasilitas souvenirshop merupakan bagian dari fasilitas pokok yang disediakan bagi wisatawan. Sebagian besar wisatawan tidak mengetahui cendera mata khas Desa Wisata Jatiluwih. Tidak dijumpai fasilitas souvenirshop yang secara khusus menjual barang kerajinan dan makanan atau minuman khas hasil karya masyarakat Desa Jatiluwih. Wisatawan hanya mendapat informasi dari guide, bahwa produk beras merah dan teh beras merah sebagai cendera mata khas desa wisata tersebut.

Dalam perkembangan Desa Wisata Jatiluwih dari aspek palemahan, diperlukan upaya-upaya agar terjaga keharmonisan antara manusia (masyarakat Desa Jatiluwih dan wisatawan) dengan lingkungan alam. Natori (dalam Ardika, 2015:60) bahwa paradigma pengembangan pariwisata berkelanjutan yang berbasis masyarakat mensyaratkan terpeliharanya mutu sumber daya alam dan budaya, meningkatnya kesejahteraan masyarakat lokal, dan terwujudnya kepuasan wisatawan.

\section{Simpulan dan Saran}

Perkembangan sosial budaya dan ekonomi Desa Wisata Jatiluwih setelah penetapan subak Jatiluwih sebagai Warisan Budaya Dunia dari aspek Tri Hita Karana berdasarkan tujuh aspek. Aspek tersebut yaitu kegotongroyongan, budaya pertanian, kesenian tradisional, organisasi sosial, lapangan kerja 
dan kesempatan berusaha, pendapatan, serta investasi. Kegotongroyongan, upacara yang berkaitan dengan aktivitas petani, dan sistem tanam padi semakin terpelihara. Kesenian tradisional semakin dilestarikan dan dikembangkan, organisasi sosial semakin dijaga keberadaannya.

Terjadi pergeseran penggunaan sapi/kerbau untuk membajak sawah ke penggunaan traktor, penggunaan pupuk organik ke pupuk anorganik. Lapangan kerja dan kesempatan berusaha, pendapatan serta investasi mengalami peningkatan. Dari aspek parhyangan, pelaksanaan upacara yang berkaitan dengan aktivitas petani tetap dilaksanakan dengan baik. Aspek palemahan diimplementasikan dengan mempertahankan sistem tanam padi, namun berjalan kurang baik pada pola tanam yang diterapkan oleh petani. Dari aspek pawongan, implementasinya cukup baik dengan adanya organisasi sosial, peningkatan lapangan kerja dan kesempatan berusaha, pendapatan serta investasi.

Partisipasi masyarakat dalam perkembangan Desa Wisata Jatiluwih setelah penetapan subak sebagai Warisan Budaya Dunia dari aspek Tri Hita Karana dikaji dari tiga tahap yaitu perencanaan, pengembangan dan pengawasan. Partisipasi masyarakat pada tahap perencanaan dan pengawasan bersifat manipulatif dan fungsional. Pada tahap pengembangan, masyarakat berpartisipasi aktif dalam pengelolaan fasilitas pariwisata dan operasionalisasi badan pengelola daya tarik wisata. Implementasi aspek pawongan berjalan kurang baik pada tahap perencanaan dan pengawasan, pada tahap pengembangan berjalan dengan baik.

Persepsi wisatawan pada implementasi aspek parhyangan baik. Persepsi wisatawan terhadap implementasi aspek pawongan dan palemahan kurang baik dalam hal pemberian informasi, kenyamanan, dan penyediaan fasilitas umum. Wisatawan memberikan apresiasi positif dari segi keamanan, pemandangan yang masih alami, dan kebersihan daya tarik wisata.

Saran yang dapat direkomendasikan yaitu untuk Pemerintah Kabupaten Tabanan, hendaknya terus memberikan dukungan, pendampingan, dan sosialisasi. Untuk Badan Pengelola Daya Tarik Wisata Jatiluwih, produk barang kerajinan (souvenir) sebagai ciri khas Desa Wisata Jatiluwih perlu dikembangan, perlu meningkatkan kemampuan kerja masyarakat lokal dalam sektor pariwisata. Untuk Masyarakat Desa Jatiluwih, harus mampu mempertahankan pengakuan Warisan Budaya Dunia, menjaga keamanan dan ketertiban di wilayah desanya, serta mencegah dan menghindari terjadinya konflik.

\section{Ucapan Terima Kasih}

Ucapan terima kasih disampaikan kepada Prof. Dr. dr. A.A. Raka Sudewi, Sp.S(K) selaku Direktur Program Pascasarjana Universitas Udayana. Prof. Dr. I Nyoman Darma Putra, M.Litt., selaku Ketua Program Studi Magister 
Kajian Pariwisata Program Pascasarjana Universitas Udayana. Apresiasi dan ucapan terima kasih juga disampaikan kepada Dr. Ir. Syamsul Alam Paturusi, MSP., sebagai Sekretaris Program Studi Magister Kajian Pariwisata Program Pascasarjana Universitas Udayana. Prof. Dr. Made Antara, M.S. dan Dr. Ir. Syamsul Alam Paturusi, MSP., sebagai Pembimbing I dan Pembimbing II. Para penguji yang terdiri dari Prof. Dr. I Nyoman Sirtha, SH.,MS., Prof. Dr. I Wayan Ardika, M.A., dan Dr. Ir. I Made Adhika, MSP., yang telah memberikan banyak masukan dan koreksi untuk penyempurnaan penelitian ini. Ucapan terima kasih juga disampaikan kepada semua pihak yang telah membantu dalam penelitian ini.

\section{Daftar Pustaka}

Ardika, I Wayan. 2015. Warisan Budaya Perspektif Masa Kini. Denpasar: Udayana University Press.

Butler, Richard. 1980. The Tourism Area Life Cycle: Application and Modifications. Great Britain: Cromwell Press.

Claiborne, Petra. 2010. "Community Participation in Tourism Development and the Value of Social Capital". Tourism and Hospitality Management. Vol. 84:1-79.

Cooper, Chris, Jhon Fletcher, David Gilbert, Stephen Wanhill. 1999. Kepariwisataan Prinsip-prinsip dan Pelaksanaan. Bagian Proyek Penerjemahan dan Penerbitan Buku-buku Pariwisata Jakarta Tahun Anggaran 1999/2000.

Cravens, David W. 1997. Strategic Marketing. Texas: Irwin.

Heny Urmila Dewi, Made, Chafid Fandeli, M. Baiquni. 2013. "Pengembangan Desa Wisata Berbasis Partisipasi Masyarakat Lokal di Desa Wisata Jatiluwih, Tabanan Bali”. Jurnal Kawistara. Vol. 2(2):117-226.

Mowforth, Martin dan Ian Maunt. 2000. Pariwisata dan yang Berkelanjutan. Pariwisata Baru di Dunia Ketiga. Jakarta: Bagian Proyek Pengembangan Literatur Pariwisata Tahun Anggaran 2000.

Musoman, Ansyari, Fadhilah Septiari, Na'immah Nur'Aini, Wardana Jaya Jasmitha. 2013. Identifikasi Dampak Ekonomi Terhadap Kawasan Wisata Taman Budaya Sentul. available at: http://www.slidersshare.net/ainiaikudou/ ekonomi-dan-bisnis-wisata-identifikasi-dampak-ekonom. diunduh pada tanggal 21 Oktober 2014.

Nuryanti, Windu. 1993. Concept, Perspective and Challenges. Naskah Lengkap Laporan Konferensi Internasional mengenai Pariwisata Budaya. Yogyakarta: Gadjah Mada University Press.

Pitana, I Gde dan Putu G. Gayatri. 2005. Sosiologi Pariwisata. Yogyakarta: Andi.

Prasiasa, Dewa Putu Oka. 2010. "Pengembangan Pariwisata dan Keterlibatan Masyarakat Di Desa Wisata Jatiluwih Kabupaten Tabanan" (disertasi). Denpasar: Program Pascasarjana Universitas Udayana.

Timothy, D. J. 1999. "Participatory Planning a View of Tourism in Indonesia” Annals of Tourism Research. Vol. 26(2). 
Universitas Gadjah Mada. 1992. Penyusunan Tata Ruang dan Rencana Detail Teknis Desa Wisata Terpadu di Bali. Yogyakarta: Fakultas Teknik.

Peraturan Pemerintah Nomor 2 Tahun 2012 tentang Kepariwisataan Budaya Bali.

\section{Profil Penulis}

Dewa Ayu Diyah Sri Widari, A.Par adalah dosen tetap di Akademi Pariwisata (AKPAR) Denpasar sejak tahun 2013. Ia menyelesaikan pendidikan pada Program Studi Diploma IV Pariwisata Universitas Udayana tahun 1995. Dari tahun 1996 sampai 2012 pernah menjadi dosen di Sekolah Tinggi Pariwisata Sahid Jakarta. 